\title{
Studies on Acaricidal Bioactivities of Artemisia judaica L. extracts against Eutetranychus orientalis (Klein), (Acari : Tetranychidae)
}

\section{Hamdy M. El-Sharabasy}

Plant Protection Department, Faculty of Agriculture, Suez Canal University, Ismailia, Egypt.

\begin{abstract}
The potential of crude extracts of Artemisia judaica L. were evaluated for toxic and repellent effect against adult females and immature stage of Eutetranychus orientalis (Klein), in the laboratory.

Ethanolic leaf extraction was more effective as toxic and repellent effect against adult females and immature stage of Eutetranychus orientalis (Klein), followed by acetone, petroleum ether and aqueous extraction $(\mathrm{P}<$ 0.05). The results indicated that adults are more susceptible to the leaf extracts than immature.
\end{abstract}

Key words: E. orientalis, A. judaica, Toxicity, Repellent.

\section{INTRODUCTION}

Spider mites (Acari: Tetranychidae) are the most important phytophagous mite pests of agricultural crops worldwide, whose population outbreaks can cause serious damage and yield losses. Among them, the citrus brown mite, Eutetranychus orientalis (Klein), is especially significant as the most polyphagous species in field and greenhouses in the Middle East, Africa, and Asia (Sewify \& Mabrouk 1991). It usually attacks citrus and is a persistent pest in Egypt, especially in Upper Egypt, preferring lemon and orange. E. orientalis is a serious pest of a wide variety of agricultural, ornamental, and medicinal plants (Rasmy 1978). 
Problems associated with the use of synthetic insecticides led researchers to look for natural plant protection compounds such as botanical insecticides and antifeedants. Botanical products are useful tools in many pest management programs because they are effective and specifically target plants natural enemies (Isman, 2006).

E. orientalis is primarily controlled by acaricides in Egypt. As long-term reliance of spider mite control on chemical acaricides has caused resistance and public concerns of residues in agroproducts (Iskander et al. 1993), it was necessary to search for alternatives to conventional pesticides such as biopesticides to control spider mites (Nauen et al., 2001).

Recently, the extracts of plants have provoked interest as sources of natural products.

Artemisia judaica L. known as wormwood grows in wild in Sinai peninsula, Egypt (Tackholm, 1974). Several isolated compound from this species have been shown plant growth regulators and cyto-toxicity (antitumor) activities (El-Massry et al., 2002, Saban et al., 2005). Essential oils of Artemisia were tested for their relative toxicity as contact acaricides to the two-spotted spider mite, T. urticae (Chiasson et al. 2001), and it was found lethal to the spider mite.

Extracts of A. judaica were tested against Spodoptera littoralis as Antifeedant and fungicidal (Abdelgaleil et al. 2008).

Some reports also showed that the other species; Artemisia annua L. was exhibited certain insecticidal and fungal bioactivities. Kordali et al. (2006) found that the essential oils separated from the aerial parts of A. апnиa exhibited obvious mortality against Sitophilus granarius L. The essential oil of $A$. аnnua showed very strong fumigant action against $S$. oryzae, $S$. zeamais, Callosobruchus chinensis and Bruchus rufimanus. Another 
research also listed the extract of A. апnua, which showed highly antifeedant action against Aphis gossypii, T. urticae (Li et al. 2000), and on Tetranycus cinnabarinus Biosduval (Zhang et al., 2008).

The aim of this work was to evaluate the toxic effects and repellency of different organic solvents extracts having different polarity of the leaves of Artemisia judaica against Eutetranychus orientalis under laboratory condition.

\section{MATERIALS AND METHODS}

\section{Mites tested}

The pure cultural of the citrus brown mite, Eutetranychus orientalis was collected from the castor oil plant (Ricinus communis L.) and reared on castor leaves as host plant under laboratory condition at $27 \pm 1^{\circ} \mathrm{C}$ and

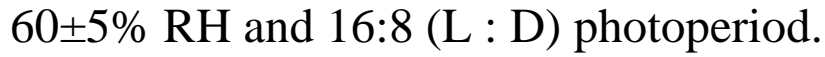

The entire plant was collected from El-Maghara region, Sinai Peninsula, identified and authenticated by a botanist at the department of Botany, Faculty of Agriculture, Suez Canal University, Ismailia, Egypt.

Leaf samples of A. judaica were left to dry under laboratory conditions for two weeks. The dry leaves were powdered using mortar and pestle and screened through an 80-mesh screen. A dried powder (40 gm) was taken and soaked using different organic solvents, Ethanol, Acetone and Petroleum ether (solvent was added at rate of $5 \mathrm{ml} / 1 \mathrm{mg}$ plant) for $48 \mathrm{~h}$. The extracts were filtered and the filtrates were evaporated till dryness in a rotary evaporator under vacuum. Each crude material obtained was weighted and re-dissolved in the suitable solvent $(1 \mathrm{~g} / 10 \mathrm{ml}$ solvent $)$, to give $10 \%(\mathrm{w} / \mathrm{v})$. 
The effect on adult females and immature stages of Eutetranychus orientalis Bioassay was performed in rearing units consisted of four castor leaf discs placed on a moist cotton pad in a Petri-dish. Four concentrations, $1.25,2.5,5$ and $10 \mathrm{gm} / \mathrm{ml}$ with four replications per concentration and control were made. Effects of the different extracts were tested separately against adult females and immature stage, (20 adult females and immature individuals/replicate). Mites were transferred to the lower surface of castor leaf discs and sprayed with different extracts. Mortality was recorded 24, 48 and $72 \mathrm{hrs}$ after treatments. Data from laboratory bioassays (cumulative mortality data for immature and adult females) were corrected using Abott's formula (Abott, 1925) and subjected to probit analysis to estimate LC $_{50}$ with 95\% confidence limit according to Finney (1971).

\section{Repellency tests}

Castor leaves were cut into discs ( $5 \mathrm{~cm}$ in diameter) of symmetrical portion along the midrib obtained per each disc. One half portion of the disc was dipped in tested concentrations and the other half was dipped in solvent as check. The treated discs were left to dry and put on moistened cotton wool in Petri-dishes. Four discs were used as replicates for each concentration. Ten adult females and immature stage were transferred on the midrib of each disc. The mites left to move freely across the two portions of the disc were counted after $24 \mathrm{hr}$ and $48 \mathrm{hr}$. The number of eggs laid on both sides was recorded after $72 \mathrm{hr}$. Repellency index were calculated according to Xie and Isman (1992).

Significant differences among mite groups, solvents and the antifeedant indexes at different treatments were compared using the analysis of variance (ANOVA) followed by Tukey's test $(P<0.05)$ for multiple comparisons where significant differences were observed.

\section{RESULTS}




\section{Direct toxicity}

The $\mathrm{LC}_{50}$ values with a $95 \%$ confidence limit and regression slope at $72 \mathrm{hr}$ exposure to different extracts of $A$. judaica and adult females and immature stage of Eutetranychus orientalis are given in Table 1.

$\mathrm{LC}_{50}$ values of adult females of Eutetranychus orientalis $(0.29,0.56,2.01$ and $110.32 \mathrm{gm} / \mathrm{ml}$ ) was lower than immature $(2.97,3.61,4.57$ and 27.13 $\mathrm{gm} / \mathrm{ml}$ ) against plant extracts, respectively.

Based on the $\mathrm{LC}_{50}$ values it can be arranged in the following descending order of effectiveness: Ethanol, acetone, petroleum ether and aqueous extraction. The data obtained show that the various extracts of $A$. judaica were the most toxic against adult females than immature stages.

The $\mathrm{LC}_{50}$ measured for adult was not significantly between ethanol and acetone extracts, but there was significant differences with petroleum ether extract and highly significant with aqueous extract (Table 1).

\section{Repellency effect}

The repellency percentage of adult females and immature of Eutetranychus orientalis and number of deposited eggs per female are shown in Table 3. The repellency percentage was highest at $10 \mathrm{gm} / \mathrm{ml}$ and $5 \mathrm{gm} / \mathrm{ml}(100 \%)$ after $24 \mathrm{hr}$ of treatment for ethanolic leaf extract. After $48 \mathrm{hr}$ of treatment, the repellency percentage was decreased. Ethanolic leaf extract was the highest repellency compared with other extracts especially aqueous extract. In case of treated adults, ethanolic extraction was highest repellency after $24 \mathrm{hr}$ of treatment followed by acetone, petroleum ether and aqueous extraction, respectively.

While, after $48 \mathrm{hr}$ of treatment, however, the repellency decreased. The same trend was observed with immature. Thus, at $48 \mathrm{hr}$ mites return to fed on treated leaves indicating that the effective organic compound in the leaf 
extract are probably volatile. Number of eggs laid by females showed a significant reduction as compared with control.

Treated females did not statistically significant between ethanol and acetone extracts, but there was significant differences with petroleum ether extract and highly significant with aqueous extract (Table 3). Mukind and Syce (2007) found that the extract of Artemisia afra was non toxic in mice and rats when administrated orally in doses up to 2000 and $1000 \mathrm{mg} / \mathrm{kg}$, respectively.

As a general trend, all treatments investigated were found repellence to adult females and immature of Eutetranychus orientalis than the control experiment at all the inspected times.

Comparison among treatments revealed no significant differences between extracts. Minimal repellent effect was observed for aqueous extracts as it expressed significantly lower repellency than the other treatments.

Table (1): $\mathrm{LC}$ values ( $\mathrm{gm} / \mathrm{ml}$ ) and probit statistics for tested extracts of A. judaica against adult and immature stage of Eutetranychus orientalis after 72 hr.

\begin{tabular}{|c|c|c|c|c|c|c|}
\hline \multirow{3}{*}{ Solvents } & \multicolumn{6}{|c|}{ Eutetranychus orientalis } \\
\hline & \multicolumn{3}{|l|}{ Adult } & \multicolumn{3}{|c|}{ Immature stage } \\
\hline & Slope & $\chi^{2}$ & $\mathrm{LC}_{50}(95 \% \mathrm{CL})$ & Slope & $\chi^{2}$ & $\mathrm{LC}_{50}(95 \% \mathrm{CL})$ \\
\hline P. ether & 17.51 & 0.1 & $4.01^{\mathrm{b}}(1.3-3.79)$ & 10.92 & 0.37 & $4.57^{\mathrm{c}}(2.13-8.72)$ \\
\hline Acetone & 13.81 & 0.9 & $0.49^{\mathrm{a}}(0.15-1.11)$ & 9.41 & 1.4 & $3.61^{\mathrm{b}}(1.39-5.32)$ \\
\hline Ethanol & 269.7 & 0.4 & $0.29^{\mathrm{a}}(0.01-0.56)$ & 63.89 & 0.1 & $2.97^{\mathrm{a}}(1.12-5.41)$ \\
\hline Water & 21.69 & 0.31 & $111.32^{\mathrm{c}}(61.43-215.27)$ & 24.01 & 0.16 & $27.13^{\mathrm{d}}(16.19-54.92)$ \\
\hline
\end{tabular}


Table (3): Repellent effect of A. judaica solvent extracts on adult and immature stages of Eutetranychus orientalis

\begin{tabular}{|c|c|c|c|c|c|c|c|}
\hline \multirow[t]{3}{*}{ Solvents } & \multirow{3}{*}{$\begin{array}{l}\text { Conc. } \\
\text { gm / ml }\end{array}$} & \multicolumn{4}{|c|}{ Eutetranychus orientalis } & \multirow{2}{*}{\multicolumn{2}{|c|}{$\begin{array}{l}\text { Average no. of } \\
\text { eggs/female after } 48 \mathrm{hr}\end{array}$}} \\
\hline & & \multicolumn{2}{|c|}{ Adult } & \multicolumn{2}{|c|}{ Immature } & & \\
\hline & & 24 & 48 & 24 & 48 & Treatment & Control \\
\hline \multirow{4}{*}{ P. ether } & 1.25 & 68.1 & 65 & 85.2 & 84.5 & \multirow{4}{*}{$1.5^{\mathrm{b}}$} & \multirow{4}{*}{6.6} \\
\hline & 2.5 & 69.2 & 66.4 & 88.7 & 85.2 & & \\
\hline & 5 & 70.7 & 69.3 & 90.5 & 81.9 & & \\
\hline & 10 & 75.9 & 77.7 & 92.3 & 82.7 & & \\
\hline \multirow{4}{*}{ Acetone } & 1.25 & 73.2 & 73.5 & 83.5 & 81.2 & \multirow{4}{*}{$1.8^{b}$} & \multirow{4}{*}{7.11} \\
\hline & 2.5 & 76.7 & 73.2 & 85.2 & 81.8 & & \\
\hline & 5 & 78.2 & 76.8 & 86.9 & 83.5 & & \\
\hline & 10 & 81.5 & 78.2 & 88.7 & 87.2 & & \\
\hline \multirow{4}{*}{ Ethanol } & 1.25 & 92.1 & 88.3 & 96.1 & 94 & \multirow{4}{*}{$1.11^{\mathrm{a}}$} & \multirow{4}{*}{4.91} \\
\hline & 2.5 & 96.9 & 90.2 & 96.1 & 91 & & \\
\hline & 5 & 100 & 90.2 & 100 & 93 & & \\
\hline & 10 & 100 & 92.1 & 100 & 97.9 & & \\
\hline \multirow{4}{*}{ Water } & 1.25 & 48.8 & 47.1 & 70.9 & 68.1 & \multirow{4}{*}{$4.41^{\mathrm{c}}$} & \multirow{4}{*}{11.13} \\
\hline & 2.5 & 50.4 & 48.8 & 73.9 & 70.9 & & \\
\hline & 5 & 51.5 & 49.3 & 75.9 & 72.4 & & \\
\hline & 10 & 53.8 & 50.4 & 76.9 & 73.9 & & \\
\hline
\end{tabular}

\section{DISCUSSION}

The current results reported the acaricidal bioactivities of A. judaica against adult females and immature stage of Eutetranychus orientalis. The leaf extracts of A. judaica had shown stronger biological activity, and there were significant differences $(P<0.05)$. These results provided basis for further screening and separation of the acaricidal activity components from A. judaica, and brought important reference value for the mite pests control new pesticides.

Herbal therapies are natural products, environmental friendly and cheap. The need for alternative, nonchemical, control strategies in crop protection systems has increased in the last decade due to development of resistant strains of mites. A. judaica is an important traditional medicine plant, and it is well known for its antimalarial activity, attributed to the presence of 
artemisinin. A. judaica contains artemisinin, artemisinic acid, methyl wormwood, artemisinic alcohol, and the volatile oil, mainly including eucalyptol, artemisia ketone, camphor, caryophyllene, oxidation caryophyllene, and so on. Volatile oil has antibacterial, antiviral, antiparasitic, the regulation of immune function, antipyretic and anti-tumor and other roles (Wei et al. 2004).

Hassanein et al., (2004) recorded that hexane, chloroform, ethyl acetate and ethanol extracts of Artemisia were toxic to the fourth instar larvae of Spodoptera littoralis . Moreover, Soliman et al.,(2005) found that successive extracts of Artemisia with petroleum ether, chloroform, ethyl acetate and ethanol were toxic for the two-spotted spider mite T. urticae The data obtained show that the various extracts of $A$. judaica were the most toxic against adult females than immature stages except the aqueous extraction. Although, the aqueous extract of Artemisia was used herein, the obtained results were in line with the finding of Abd-Elshafy et al., (2007) who found that diethyl ether, ethyl acetate and ethanol extracts of Artemisia manifested the highest toxicity against larvae of Hylomma dromedarii.

Shekari et al. (2008) showed that the methanolic extract of A. аnnua has antifeedant effect on X. luteola. Abdelgaleil et al. (2008) tested that the two essential oils of A.judaica namely piperitone and trans-ethyl cinnamate as antifeedant activity against the third instar larvae of Spodoptera littoralis (Boisd). They found that trans-ethyl cinnamate was more toxic than piperitone. The same two essential oils when tested for antifungal activity against four plant pathogenic fungi, the isolated compounds exhibited a moderate to high activity.

Tripathi et al. (2000) showed that adults of Tribolium castaneum were more susceptible to cineole which had been extracted from Artemisia annua. Ahmed et al (2009) found that the cold Artemisia aqueous extracts 
(Soaking) is more effective than the hot extract (Boiling), and mentioned that this could be due to boiling has a negative effect on the active component of the herb. The different extracts possess a fairly good mite repellency against adult females and immature stage of Eutetranychus orientalis after 24 and $48 \mathrm{hr}$ of treatment, this might due to the main component in A. judaica as eugenol, carnation oil, -pinene and geraniol. The effect of A. judaica extract on Eutetranychus orientalis indicates that the extract affect either feeding behavior acting like a deterrent or biochemical processes including digestion and metabolism. However, after 2 days the chemical may evaporate from the leaf or loose its potency and this may explain the loss of deterrency.

Saber (2004) found that Artemisia monosperma, have repellency, mortality and oviposition deterrent effects against female of T. urtica. Abdel-Shafy et al., (2009) found that Hexane, ethanol extracts and diethyl ether extracts of Artemisia herba-alba and ethyl acetate extract of A. monosperma were highest effect against the third instar larvae of Chrysomyia albiceps. Shekari et al. (2008) found that the methanolic leaf extract of Artemisia аппи $\mathrm{L}$. was effective against $3^{\text {rd }}$ instars larvae and adult of elm leaf beetle Xanthogaleruca luteola Mull., with $\mathrm{LC}_{50} 48 \%$ and $43.77 \%$ for adult at 24 and $48 \mathrm{hr}$, respectively.

The need for new natural pesticides with different mode of action of the entire plant demonstrated here may encourage further studies on their using as biodegradable and mammalian and environmentally safe mites control agents. 


\section{REFERENCES}

Abbott, W. S. (1925): A method of computing the effectiveness of an insecticide. J. Econ. Ent., 18:265-267.

Abdelgaleil, S.A.M.; Abbassy, A.M.; Belal, A.H. and Abdel Rasoul M. A.A. (2008): Bioactivity of two major constituents isolated from the essential oil of Artemisia judaica L. Bioresource Technology 99: 5947-5950.

Abdel-Shafy, S., M. Soliman, S.M. Habeeb, 2007. Invitro acaricidal effect of some crude extracts and essential oils of wild plants against certain tick species. Journal of Acarologia, XLVII: 33-42.

Abdel-Shafy, S. \& El-Khateeb, R.M. \& Soliman, M. M.M. \& Abdel-Aziz, M.M. (2009): The efficacy of some wild medicinal plant extracts on the survival and development of third instar larvae of Chrysomyia albiceps (Wied) (Diptera: Calliphoridae). Trop Anim Health Prod., 41:1741-1753.

Ahmed, W.M; Habeeb, S. M.; El Moghazy, M.F and Hanafi, E.M. (2009): Observation on Pediculosis in Buffalo-Cows with Emphasis on its Impact on Ovarian Activity and Control by Herbal Remedies. World Applied Sciences Journal 6 (8): 1128-1138

Ay, R. (2005): determination of susceptibility and resistance of some greenhouse populations of Tetranychus urticae Koch to chlorpyrifos (Dursban 4) by the Petri dish-Potter tower method. J. Pest. Sci., 78: 139-143.

Chiasson, H.; Bélanger, A; Bostanian, N.; Vincent, C.and Poliquin A. (2001): Acaricidal properties of Artemisia absinthium and Tanacetum vulgare (Asteraceae) essential oils obtained by three methods of extraction. J. Econ. Ent., 94, 167-171. 
El-Massry, K.F.; El-Ghorab, A.H. and Farouk, A. (2002): Antioxidant activity and volatile components of Egyptian Artemisia judaica L. Food Chem. 79, 331-336.

El-Sharabasy, H.M. (2010): Acaricidal activities of Artemisia judaica L. extracts against Tetranychus urticae Koch and its predator Phytoseiulus persimilis Athias Henriot (Tetranychidae : Phytoseiidae). J. of Biopesticides, 3(2):514 - 519.

Finney. D. J. (1971): Probit Analysis $3^{\text {rd }}$ ed., Cambridge Univ. Press, London. 383 pp.

Hassanein, A.A., Abou-Yousef M.H., Soliman M.M. and Shaaban M.N., 2004.The biological effects of certain plant extractions against cotton leafworm The second international conference on the Role of Biochemistry in Environment and Agriculture pp: 404-414

Isman, M.B. (2006): Botanical insecticides, deterrents, and repellents in modern agriculture and an increasingly regulated world, Ann. Rev. Entomol. 51 45-66.

Kordali, S.; Aslan, I.; Calmasur, O. and Cakir, A. (2006): Toxicity of essential oils isolated from three Artemisia species and some of their major components to granary weevil, Sitophilus granaries (L.) (Coleoptera: Curculionidae). Industrial Crops and Production, $23,162-170$.

Li, Y. S.; Tang, S. Z.; Zou, H. Y.; Wang, L. X.; Yang, Y. Z.; Li, W. Y.; Na, X. Y. and Er, Z. (2000): Insecticidal activity of extracts from Artemisia annua. Pesticide, 39, 25-26.

Marco, J.A. and Barbera, O. (1990): Natural products from the genus Artemisia L. In: Atta-ur-Rahman (Ed.), Studies in natural products chemistry, vol. 7 Elsiever Science Publishers BV, Amsterdam, pp. 201-264. 
Nauen, R.; Stumpf, N.; Elbert, A.; Zebitz, C.P.W. and Kraus, W. (2001): Acaricide toxicity and resistance in larvae of different strains of Tetranychus urticae (Acari : Tetranychus). Pest Manage. Sci., 57: 233-261.

Saban, K., Recep, K., Ahmet, M., Ahmet, C.A.A., Ali, Y., 2005. Determination of the chemical composition and antioxidant activity of the essential oil of Artemisia dracunculus and of the antifungal and antibacterial activities of Turkish Artemisia absinthium, Artemisia dracunculus, Artemisia santonicum, and Artemisia spicigera essential oils. J. Agric. Food Chem. 53, $9452-$ 9458.

Saber, S.A., 2004. Influence of Artemisia monosperma Del. Extracts on repellency, oviposition deterrence and biological aspects of the two-spotted spider mite Tetranycus urticae Koch. Egypt. Journal Biological pest Control, 14: 345-348.

Shekari, M.; Sendi, J.J.; Etebari, K.; Zibaee, A. and Shadparvar, A.(2008): Effects of Artemisia annua L. (Asteracea) on nutritional physiology and enzyme activities of elm leaf beetle, Xanthogaleruca luteola Mull. (Coleoptera: Chrysomellidae). Pesticide Biochemistry and Physiology 91: 66-74.

Soliman M., Saber S.A. and Amer. S.A.A., 2005 Toxocological evaluation of the desert plant Artemisia monosperma Delile extracts and their isolates on the two-spotted spider mite, Tetranychus urticae Koch. Egypt Journal of Biology and Pest Control, 15: 113-117.

Tackholm, V. (1974): Student Flora of Egypt, 2nd ed. Cairo University Press, Cooperative printing Co., Beirrut, Lebanon, p. 581. 
Tripathi, A.K.V. ; Prajapati A.K., Aggarwal-Khanuja S.P.S., Kumar S., (2000): Repellency and toxicity of oil from Artemisia annua to certain stored product beetles, J. Econ. Entomol. 93 43-47.

Tunon, H.; Thorsell W.; Mikiver A. and Malander I. (2006): Arthropod repellency, especially tick (Ixodes ricinus), extracted by extract from Artemisia abrotanum and essential oil from flowers of Dianthus caryophyllum. Fitoterapia 77: 257-261.

Wei, X. G.; Dong Y.; Cui Q. X. and Zhang G L. (2004): GC/MS analysis of chemical constituents of volatile oil in uncultivated Artemisia аппиа L. in Dezhou. Journal of Shandong University of TCM, 28, $140-143$.

Xie, Y.S. ; Isman, M.B. (1992): Antifeeding and repellent effect of Meliaceous plants to some insect pest, J. South. China. Agri. Univ. $41-7$

Zhang, Y. Q.; Ding, W.; Zhao, Z. M.; WU, J. and Fan, Y.H (2008): Studies on Acaricidal Bioactivities of Artemisia апnиа L. Extracts Against Tetranychus cinnabarinus Bois. (Acari: Tetranychidae). Agricultural Sciences in China, 7(5): 577-584. 